кандидат педагогічних наук, докторант

(Херсонський державний університет) bogomolova-77777@ukr.net

ORCID : $\odot \odot \odot \odot-\odot \odot \odot 2-996 \odot-9443$

\title{
СОЦАЛЬНЕ ВИХОВАННЯ ДІТЕЙ КРІЗЬ ПРИЗМУ КОДЕКСУ ЗАКОНІВ ПРО НАРОДНУ ОСВІТУ УСРР (ЛИСТОПАД 1922 р.)
}

У статті подається аналіз передумов прийняття Кодексу законів про народну освіту УСРР у листопаді 1922 року, розкриваються теоретичні основи і иляхи практичної реалізачії системи сочіального виховання на початку 20-х років ХХ ст., визначених Деклараџією про сочіальне виховання дітей, прийнятою урядом краӥни в 1920 р.

Особливу увагу приділено змістовому та управлінському аспектам дослідження.

Ключові слова: кодекс законів, сочіальне виховання, мережа дитячих закладів, охорона дитинства, організаційно-педагогічне забезпечення, органи управління, Головсоцвих.

Постановка проблеми. Відбудова демократичного суспільства i проведення політичних, економічних, соціальних та освітніх реформ в Україні детермінують зміни в системі освіти, що актуалізує пошук нових наукових підходів до визначення стратегічних напрямів виховання підростаючого покоління, в тому числі і соціального.

Ефективним шляхом підвищення рівня діяльності органів управління освітою, шкіл, позашкільних навчальних закладів, громадських дитячих об'єднань є об'єктивний критичний аналіз історикопедагогічного досвіду, у межах якого вагоме значення посідає дослідження становлення та розвитку системи соціального виховання в Україні в 20-х - 30-х роках ХХ ст. Особливо важливими в цей період були послідовні дії уряду країни, Наркомосу УСРР, Головсоцвиху та його відділів з цих питань.

Зауважимо, що важливі проблеми виховання дітей в тогочасних умовах мали етапність розв'язання, визначалися нормативно-правовими урядовими постановами, наказами, розпорядженнями, які стосувалися, як окремих нагальних питань (проведення нарад, з'їздів з освіти; організацію дитячих будинків, літніх і лісних шкіл; дитячих санаторіїв; облік дітей-сиріт та забезпечення їх харчами, пайками; проведення "Тижня захисту дітей" та ін.), так і визначали комплекс заходів, щодо реформування освіти УСРР у цілому в 20-х - 30-х роках ХХ ст. До таких відносимо Кодекс законів про народну освіту УСРР (1922р.), який мав свої особливості творення та реалізації, що і визначило тему нашої публікації.

Матеріали дослідження та його методи. Слід зазначити, що окремі аспекти необхідності прийняття цього Кодексу і його вплив на розвиток вітчизняної освіти стали предметом дослідження сучасних українських науковців: В. Бондаря, Л. Бондар, Л. Вовк, І. Зайченка, Н. Коляди, О. Сухомлинської, В. Федяєвої, Т. Янченко та ін. Їхні дослідження мають як узагальнюючий характер, де в комплексі розкриваються проблеми освітньої політики, розбудови національної освіти, оригінальність і самобутність української концепції та моделі освіти, навчання і виховання дітей, діяльність педагогів та громадських діячів цього періоду, так і окремі питання соціального виховання в загальній освітній системі УСРР.

Мета нашої публікації - розкриття стану реформування освітньої галузі в країні у період обгрунтування та прийняття Кодексу законів про народну освіту УСРР (листопад 1922 р.), зокрема в контексті реалізації Декларації про соціальне виховання дітей в УССР (1920р.).

Методи дослідження. Для досягнення поставленої мети статті використано такі методи дослідження: історіографічний аналіз історико-педагогічної літератури, аналіз, синтез та узагальнення архівних матеріалів.

Виклад результатів дослідження. Як зазначає Л. Березівська, "... 1921 рік став роком перетворення Наркомосу в єдиний центр забезпечення освітньої галузі в УСРР" [1: 172].

Провідне місце в діяльності якого посіли питання реалізації концепції соціального виховання, що знайшло подальше унормування і визначення шляхів практичної реалізації у Кодексі законів про народну освіту УСРР (1922 р.).

Аналіз творення і прийняття цього документу свідчить, що він укладений на основі широкого спектру законодавчих матеріалів ВУЦВК за 1920-1922 рік, Декларації про соціальне виховання дітей в УСРР (1920) [2].

Зокрема, у своїй доповіді "Про Кодекс законів по народній освіті" Я. П. Ряппо (1880-1958) заступник наркома освіти УСРР (1921-1928) зазначав, що його прийняття пов'язано, як із реформуванням освітньої галузі в цілому, так і з тим, що "... в 1920 р. висувається і розширюється проблема соціального виховання" [3: 140]. 
Кодекс затверджувався для уточнення (унормування) правових основ реалізації концепції соціального виховання, для визначення практичних шляхів реалізації соціальних питань, що постали перед країною: ліквідація такого явища, як діти-безхатченки (ліквідація безпритульності) а також - професійна підготовка робітничих кадрів для промисловості і аграрного сектору (сільськогосподарського виробництва). Структура Кодексу становила: Вступ; 4 розділи (книги): 1. "Організація управління і постачання народної освіти", 2. "Соціальне виховання дітей", 3. "Професійна і спеціально-наукова освіта", 4. "Політична освіта і виховання дорослих". Ці розділи конкретизувалися у 762 статтях. У вступі визначалися основні принципи організації, мета і завдання освіти й виховання в УСРР. Досить різнотиповою і обгрунтованою стала за цим документом структура освіти в країні. Уточнювалося, що одним із головних завдань УСРР є навчання і виховання дітей і молоді під керівництвом Наркомоса; мета - "розкріпачення трудящих мас від духовного рабства, розвиток їхньої самосвідомості, створення нового покоління 3 твердою волею, суспільно необхідною кваліфікацією i 3 матеріалістичним світоглядом, що грунтується на чіткому розумінні законів розвитку природи і суспільства" [4: 3].

Окремо визначалися завдання щодо управлінських органів і структур, відповідальних за таку роботу - виховання покоління будівників нового суспільства. За основу роботи всіх закладів освіти було взято працю (трудовий підхід), життєдіяльність людини. Навчально-виховний процес спрямовувався на конкретну, практичну діяльність. Закріплювалося право всіх громадян без винятку на вільний доступ до різних форм (різних рівнів) освіти в тому числі і професійного виховання. У законодавчому полі визначалася і сама система освіти: соціальне виховання дітей; професійна освіта, відповідно віку дітей і молоді; наукова робота й політична освіта серед дорослого населення (особливість в тому, що ці два напрямки роботи поєднувалися, доповнювали один одного, хоча зрозуміло, що наукова робота має свою мету, завдання і функції, одночасно певним чином і торкається науково-просвітницької роботи, складовою якої і була політико-просвітницька діяльність). Навчання і виховання дітей до 17-ти річного віку стало обов'язковим, безкоштовним (безоплатним), спільним для хлопчиків і дівчаток. Також уточнювалися джерела фінансових надходжень: державні (центральні і місцеві), від трудових колективів (підприємств, установ, організацій, аграрного сектору), власних надходжень (шкільних господарств) та інші. Визначалася і сама структура управління закладів освіти та наукових установ на різних рівнях:

Народний комісаріат освіти - вищий контролюючий державний орган до якого входили: Народний комісар освіти, його заступник, колегія, секретаріат, фінансово-економічне управління, головний комітет соціального виховання дітей, головний комітет професійної і спеціально-наукової освіти, головний політико-освітній комітет, Державне видавництво, рада щодо освіти національних меншин. Функції цих структур були спрямовані на успішну роботу органів і установ, які входили до підпорядкування Наркомосу, в тому числі і заклади безпосередньої професійної підготовки (курси, профшколи, технікуми, інститути, школи робітничої молоді, вечірні робітничі технікуми, робітничі факультети). Також ця система включала: Науковий комітет Наркомосу, Українська академія наук, науково-дослідні кафедри та інститути, наукові асоціації та товариства, Всеукраїнський комітет сприяння вченим та ін.) [4]. Усі підструктури Наркомосу опікувалися (вирішували) питаннями фінансування, матеріального та соціального забезпечення всієї учнівської молоді, видавничою діяльністю тощо. Здійснювали організаційно-педагогічне забезпечення функціонування освітньої галузі в країні.

3 огляду на предметне поле нашого дослідження - соціальне виховання - ми особливу увагу приділили другій книзі (тому) Кодексу законів про народну освіту УСРР - "Соціальне виховання дітей". Ïї аналіз дає підстави виокремити окремі блоки проблеми уточнення таких педагогічних категорій, як завдання та система соціального виховання, мережа установ соціального захисту дітей різних категорій.

Аналіз показав, що при визначенні типу навчального закладу для неповнолітніх враховувався їхній загальний розвиток (нормальні діти), поведінка (правопорушники), фізичний i розумовий стан (дефективні діти). До мережі таких закладів входили також приймальники, дослідно-педагогічні станції колектори в яких відбувалося обстеження, дослідження, вивчення неповнолітніх та відповідний розподіл неповнолітніх до дитячого закладу, який відповідав вимогам їхнього подальшого виховання та навчання. Велика увага в цій мережі надавалася позашкільним закладам (дитячі клуби, бібліотеки, дитячі організації). До неї входили комісії у справах неповнолітніх, а також інститут патронату.

Як свідчать архівні джерела, дослідження вченими-істориками питань розвитку і становлення освіти в Україні в 20-х - 30-х роках, матеріали постанов з цих питань інших союзних республік, зокрема і РСФРР, Кодекс був особливим, різнився з нормативним документом, зокрема, радянських республік своїми грунтовно визначеними кроками реалізації соціального виховання.

Над Кодексом активно працювали саме представники Головного комітету (відділу) соціального виховання при Наркомосі, який очолював В. Є. Бутвін, до якого також входили відповідні підвідділи: науково-педагогічний - керівник О. І. Попов, соціально-правової охорони дитинства - керівник Берлін, дитячих закладів - керівник В. О. Арнаутов, організаційно-інструкторський - керівник А. І. Гендрихівська. У роботі комітету активно працював відомий вітчизняний психолог, фундатор теоретичних основ діяльності дитячого колективу I. П. Соколянський та ін. 
Учені-організатори освіти активно працювали як над теоретичними питаннями, так і над пошуком ефективних форм реалізації завдань соціального виховання через різні підходи, методи, прийоми, засоби роботи.

Зокрема, на науково-теоретичному рівні вивчалися (досліджувалися) наступні питання: завдання, мета й результати, досягнення педології; виховання як єдиний педагогічний процес; особливості виховання дітей різного віку; фізичне виховання дітей; статеве виховання; виховання дефективної дитини (виховання дитини з певними дефектами); соціальне виховання в контексті розвитку (появи) нових суспільно-політичних процесів; дитячий колектив як провідна форма реалізації мети і завдань соціального виховання; методи соціального виховання; типи дитячих установ; дитячий будинок і шляхи розвитку взаємодії школи та дитячого будинку (від школи до дитячого будинку; школа i дитячий будинок в системі соціального виховання); єдиний навчальний план - особливості побудови; естетичне виховання в системі соціального виховання; облік праці в дитячих установах; питання підготовки соціальних педагогів (вихователів) [5].

Кожен підвідділ Головсоцвиху проводив відповідну організаційно-педагогічну роботу, що сприяло втіленню у життя визначених урядом завдань. Так, науково-педагогічним підвідділом під керівництвом його завідувача О. І. Попова було створено кабінет соціального виховання, в якому працювали окремі комісії, які розробляли досить широке коло навчальних, зокрема, питань використання дитячої книжки, іграшки, казки у соціальному вихованні.

Велика увага приділялася розгляду впливу соціальних факторів (урахування соціальних факторів) на виховання дітей.

Досить велике значення мала робота створеної при відділі у 1922 році Комісії дитинознавства, діяльність якої була пов'язана 3 питаннями вивчення і дослідження дитини, що включало: обгрунтування покрокового плану дій (був як план, так і схема за якою рухалися (просувалися учені) у своєму науковому пошуці, працюючи 3 психосоціологічними схемами). Для таких досліджень додавалися інструкції, зокрема, інструкція антропометричних досліджень [5: 154].

Головсоцвих мав свій орган управління - колегію на засіданні якої розглядалися результати теоретичних i практичних напрацювань, вони затверджувалися i 3 відповідними рекомендаціями подавалися до колегії Наркомосу для прийняття відповідних рішень.

У Кодексі визначалися шляхи суттєвої зміни змісту, організації і методів навчально-виховної роботи школи, за яких виховання стоїть поряд з іншими (завданнями розбудови країни - М. Богомолова) майже як "військове" завдання, що вимагає величезного прискорення в здійсненні надзвичайних заходів i відносно масштабності і відносно точності виконання [4]. При цьому вся система освіти вибудовувалася із урахуванням історичних, соціальних, національних особливостей розвитку країни. За ним (Кодексом) всі без винятку діти мали охоплюватися навчально-виховною роботою, особлива увага приділялася дітям-сиротам та дітям-безхатченкам. 3 позиції сьогодення, з практики виконання школою своїх завдань можна констатувати, що документ мав як позитивні результати, так і прорахунки, зокрема, ідея заміни школи професійними закладами, покладання повної відповідальності за виховання дітей на державні органи, зокрема дитячі заклади та установи, визнання сім’ї такою, яка не спроможна виховувати дітей належним чином [6: 106-111].

У ньому визначалися основні принципи організації освіти в країні: узгодження освітніх планів та перспектив розвитку з завданнями соціально-економічних перетворень в країні; урахування життєвих умов та інтересів людини, мати тісний зв'язок із народним господарством і державним будівництвом тощо. Мета навчання і виховання дітей чітко підпорядковувалася загальному курсу розбудови країни та партійній ідеології.

Основу навчання і виховання за цим Кодексом становили трудовий процес, життєві потреби, практична діяльність, структура системи народної освіти, що включала різні форми і типи освітніх, навчально-виховних закладів, які зреалізовували соціальне виховання дітей, професійну освіту юнацтва i молоді, наукову роботу і політичну просвіту населення.

У контексті нашого дослідження особливо необхідно звернути увагу на те, що соціальне виховання дітей і навчання в профшколах і на курсах до 17-ти річного віку, включно, оголошувалося всезагальним, обов'язковим, безкоштовним і спільним для хлопчиків та дівчаток. Послідовне і планомірне втілення цих завдань покладалося на Народний комісаріат освіти УСРР, якому підпорядковувалися всі виховні, навчальні і наукові установи і організації країни, а також різні відомства, профспілкові, кооперативні та інші організації, що проводили окремі виховні заходи, просвітницьку роботу. Уся робота узгоджувалася з Наркомосом УСРР та відповідальними, уповноваженими ним органами управління освіти на місцях. Було також чітко прописано фінансове і ресурсне забезпечення закладів системи освіти: державне (із центральних і місцевих ресурсів), надходження від трудових колективів, шкільних господарств та ін.

Слід зазначити, що в цьому Кодексі вперше визначалися принципи організації освіти не тільки дітей та молоді, але й усього населення. За законом усі навчальні заклади проголошувалися державними, освіта стала безкоштовною, доступною для всіх верств населення і обов'язковою, хлопчики і дівчатка 
навчалися і виховувалися спільно.

"Кодекс" затверджував наступність двох етапів освіти: перший - соціальне виховання, яке охоплювало дітей від народження до 15 -ти років; другий - професійна освіта - зміст якої (фахової підготовки) відповідав основним промисловим і сільськогосподарським галузям народного господарства і культури. Основними типами навчальних закладів були: дитячий будинок, дитячий садочок (діти у віці від 4-х до 8-ми років), трудова школа (діти у віці від 8-ми до 15-ти років). Окремо створювалися заклади для неповнолітніх правопорушників [4].

Система соціального виховання включала наступні типи позашкільних установ і організації: дитячий клуб, дитячу бібліотеку, дитячі організації.

Професійна освіта вибудовувалася на базі трудової семирічки за професійним спрямуванням $\mathrm{i}$ відповідно до змісту знань та практичних навичок: індустріально-технічна, сільськогосподарська, медична, педагогічна, художня. Фахівців готували у професійних школах, технікумах, інститутах, на курсах.

Мова викладання в навчально-виховних закладах установлювалася Наркомосом, узгоджувалася 3 органами місцевого самоврядування, які мали забезпечити все населення, в тому числі і національних меншин, навчанням рідною мовою.

Особливість цього Кодексу полягала в тому, що "школа відокремлювалася від церкви"; виховання і освіта були вільними від будь-якого релігійного впливу; заборонялося долучати дітей та молодь, яка не досягла 18-ти річного віку до релігійних заходів; створювалася широка система антирелігійної пропаганди.

Не оминули автори Кодексу і питання науково-методичного забезпечення організації навчальновиховного процесу, акцентувавши увагу на використанні нових методів, побудованих на досвіді та практиці.

Л. Д. Березівська у своїх дослідженнях зазначає: "Кодекс законів про народну освіту в УСРР унікальний документ, аналогічного якому в той час не було ні в Росії, ні в будь-якій іншій республіці Союзу. Кодекс законодавчо закріпив теоретичні та практичні напрацювання українського Наркомосу під керівництвом Г.Ф. Гринька, надав їм юридичної норми, якою повинні були керуватися всі освітяни України" [1:35].

Висновки та перспективи подальшого дослідження проблеми. Отже, дослідження показало, що на початку 20-х років XX ст. ідея соціального виховання була системоутворюючою і визначала зміст, характер, принципи, форми, методи, прийоми і засоби навчання і виховання дітей в Україні. У цей період виокремилася особлива мережа дитячих закладів, у яких вирішувалися питання соціального захисту дітей, навчання, проживання, харчування, медичної допомоги тощо. Мова йшла про охорону дитини, охорону дитинства. Цьому сприяла постійна урядова увага, концентрація всіх заходів під керівництвом Наркомосу освіти, прийняття важливих нормативних документів, зокрема Кодексу законів про народну освіту УСРР (1920 p.)

Його реалізація на наступних станах (періодах) розвитку системи соціального виховання зазнала суттєвих змін у процесі соціально-політичних змін у країні, що вимагає подальшого дослідження.

\section{СПИСОК ВИКОРИСТАНИХ ДЖЕРЕЛ ТА ЛІТЕРАТУРИ}

1. Березівська Л. Д. Реформування шкільної освіти в Україні у XX столітті : [монографія] / Л. Д. Березівська. К. : Богданова А. М., 2008. - 406 с.

2. Декларація Наркомосвіти УСРР про соціальне виховання дітей (1.07. 1920) // Пролет. освіта (Вінниця). 1921. - № 1. - С. 2-4.

3. Ряппо Я. Система народного просвещения Украины : [сб. материалов, ст. и докл.] / Я. Ряппо. - Х. : Гос. издво Украины, 1925. - 231 с.

4. Кодекс законов о народном просвещении УССР, утвержденный ВУЦИК 2 ноября 1922 г. на основании Постановления III сессии VI созыва ВУЦИК от 16 октября 1922 г. - Х. : Издание народного комиссариата просвещения УССР, 1922. - 767 с.

5. Операційний план Українського головного комітету соціального виховання дітей на 1922 р. та звіти про його діяльність за 1921-1922 академічний рік і серпень, жовтень 1922. - Ф. 166, оп. 2, спр. 1619, 208 арк.

6. Федяєва В. Л.Сімейне виховання в історичній ретроспективі : [монографія] / В. Л. Федяєва. - Херсон : ХДУ, 2008. $-350 \mathrm{c}$

7. Українська педагогіка в персоналіях : навч. посібник у 2-х кн. / [за ред. О. В. Сухомлинської]. - К. : Либідь, 2005. - Кн. 2. -552 c.

\section{REFERENCES (TRANSLATED \& TRANSLITERATED)}

1. Berezivska L. D. Reformuvannia shkil'noi osvity v Ukraini u XX stolitti [Reformation of School Education in Ukraine in the $20^{\text {th }}$ Century] : [monohrafiia] / L. D. Berezivska. - K. : Bohdanova A. M., 2008. - $406 \mathrm{~s}$.

2. Deklaratsiia Narkomosvity USSR pro sotsial'ne vykhovannia ditei (1.07.1920) [Declaration of the People's Commissariat of the USSR about the Social Upbringing of Children (1.07.1920)] // Prolet. osvita (Vinnytsia) [Proletarian Education]. - 1921. - № 1. - S. 2-4. 
3. Riappo Ya. Systema narodnoho prosveshcheniia Ukrainu [System of Public Education in Ukraine] : [sb. materialov, st. y dokl] / Ya. Riappo. - Kh. : Hos. yzd-vo Ukrainu, 1925. - 231 s.

4. Kodeks zakonov o narodnom prosveshchenii USSR, utverzhdennyi VUTSYK 2 noiabria $1922 \mathrm{~h}$. na osnovanii Postanovleniia III sessii VI sozyva VUTSYK ot 16 oktiabria 1922 h [The Code of National Education of the USSR Approved by the Central 2 November, 1922, Based on the Resolution of the III Session of the VI Convocation Central from 16 October 1922]. - Kh. : Izdaniie narodnoho komissariata prosveshcheniia USSR, 1922. - $767 \mathrm{~s}$.

5. Operatsiinyi plan Ukrainskoho holovnoho komitetu sotsial'noho vykhovannia ditei na $1922 \mathrm{r}$. ta zvity pro yoho diial'nist za 1921-1922 akademichnyi rik i serpen', zhovten' 1922 [The Operational Plan of the Ukrainian Main Committee on Social Upbringing of Children in 1922 and Reports on Its Activities during the 1921-1922 Academic Year August, October, 1922]. - F, 166 op. 2, spr. 1619, 208 ark.

6. Fediaieva V. L. Simeine vykhovannia v istorychnii retrospektyvi [Family Education in Historical Perspective] : [monohrafiia] / V. L. Fediaieva. - Kherson. : KhDU, 2008. - 350 s.

7. Ukrains'ka pedahohika v personaliiakh [Ukrainian Pedagogics in Personalities] : [navch. posibnyk u 2-kh] / [Za red. O. V. Sukhomlynskoi]. - K. : Lybid, 2005. - kn. 2. - 552 s.

\section{Богомолова М. Ю. Социальное воспитание детей сквозь призму Кодекса законов о народном образовании УССР (ноябрь 1922 2.).}

В статье дается анализ предпосылок принятия Кодекса законов о народном образовании УССР 6 ноябре 1922 года, раскрываются теоретические основы и пути практической реализации системы социильного воспитания в начале 20-х годов ХХ в., определенные Декларацией о социальном воспитании детей, принятой правительством страны в 1920 г.

Особое внимание уделено содержательному и управленческому аспектам исследования.

Ключевье слова: кодекс законов, сочиальное воспитание, сеть детских учреждений, охрана детства, организационно-педагогическое обеспечение, органы управления, Главсоивосп.

\section{Bogomolova M. Yu. Social Education of Children by the Prism of the People's Education Pandeckt of the USSR (November 1922).}

The article analyzes the preconditions for the adoption of the Code of Laws on the National Education of the USSR in November 1922, reveals the theoretical foundations and ways of practical implementation of the system of social education in the early 20's of the twentieth century, as defined by the Declaration on the social upbringing of children adopted by the Government of the country in 1920.

Particular attention is paid to the content and management aspect of the study.

Effective way of raising the level of the educational authorities activity, schools, out-of-school educational institutions, public children's associations is an objective critical analysis of historical and pedagogical experience, within which the study of the formation and development of the system of social education in

Ukraine in 20's 30's XX century. Of particular importance during this period were the successive actions of the Government of the country, the People's Commissariat of the Ukrainian SSR, Golovsotcvychu and its departments on these issues.

In the early 20's of the XX century the idea of social education was system-forming and determined the content, nature, principles, forms, methods and means of children's teaching and upbringing in Ukraine. During this

period a special network of children's institutions was set up in which the issues of social protection of children, education, accommodation, nutrition, medical care, etc. were addressed. It was about child protection,

childhood protection. This was aided by constant governmental attention, concentration of all activities under the leadership of the Education Commissariat, adoption of important normative documents, in particular the Code of Laws on the National Education of the USSR (1920).

Key words: code of laws, social upbringing, network of children's institutions, child protection, organizational and pedagogical support, governing, Golovsotcvych. 